Disponível em



\title{
Intellectual Capital: Perceptions of Productivity and Investment
}

\author{
Aristides Isidoro Ferreira * \\ E-mail: aristidesif@gmail.com \\ Instituto Universitário de Lisboa - ISCTE \\ Lisboa, Portugal. \\ Luís Fructuoso Martinez \\ E-mail: luis.martinez@iscte.pt \\ Instituto Universitário de Lisboa - ISCTE \\ Lisboa, Portugal.
} permitido citar parte de artigos sem autorização prévia, desde que seja identificada a fonte 


\title{
Resumo
}

Pretende-se estudar a influência do capital intelectual nas percepções dos colaboradores, quer ao nível dos investimentos realizados pela empresa, como ao nível da produtividade. Os dados foram obtidos junto de uma amostra de 440 colaboradores de 13 empresas portuguesas. Com recurso à ANOVA e Análises de Regressão, procurou-se compreender o impacto das três dimensões da Escala de Capital Intelectual ao nível das percepções de investimento e de produtividade organizacional. Os resultados mostram que as empresas com maiores valores de Capital Estrutural resultam numa percepção reduzida de investimento em recursos humanos e investigação, bem como numa elevada percepção de investimento em áreas de mercado e vendas. Foi ainda possível identificar que os colaboradores das empresas com maiores valores de Capital Estrutural as percepcionam como sendo as mais produtivas. Pelo contrário, organizações com maior investimento em Capital de Clientes tendem a associar-se a uma menor percepção de produtividade organizacional.

Palavra-chave: capital intelectual; clientes; estrutural; produtividade; investimentos.

\begin{abstract}
This study focuses on the influence intellectual capital has on employees' perceptions as related to both company investments and productivity levels. The data was obtained from 440 employees at 13 Portuguese companies. Both ANOVA and Regression Analysis were conducted in order to understand the impact three Intellectual Capital Scale components have on perceptions of investment and organizational productivity. Results show that companies with higher scores of Structural Capital have a lower perception of investment in human resources and research, as well as a higher perception of investment in marketing and sales. Moreover, employees of companies with higher Structural Capital scores also have higher perceptions of productivity. On the other hand, organizations with higher investment in Customer Capital tend to be associated with a lower perception of organizational productivity.
\end{abstract}

Key words: intellectual capital; customers; structural capital; productivity; investments. 


\section{Introduction}

As a result of the shift from the Industrial Age to the Information Age, knowledge has become a key factor in achieving and sustaining competitive advantages at an organizational level (Nicolacida-Costa, 2002). In fact, the 21 st century posits a new management paradigm based on knowledge and Intellectual Capital (IC) measurement (Conner \& Prahalad, 1996; Davenport \& Prusak, 1998). According to Bontis (1998), IC refers to the intangible assets of an organization (i.e., those that are not directly recorded in financial statements). IC is a relatively recent term in organizational behavior and its origins can be found in the work of Edvinsson and Malone (1997). However, previous research had already stressed the importance of intangible resources in organizations, such as human capital (e.g., Becker, 1964; Flamholtz \& Lacey, 1981; Snell \& Dean, 1992), organizational learning (e.g., Argyris \& Schon, 1978; Duncan \& Weiss, 1979), absorptive capacity (e.g., Cohen \& Levinthal, 1990) and interpretation systems (e.g., Daft \& Weick, 1984).

Measurement of intangibles turned out to be imperative in modern organizations in order to assess high quality (organizational) processes concerning research and technological development (Abeysekera, 2005; Dierickx \& Cool, 1989; Henderson \& Cockburn, 1994; Hudson, 1993; Klein, Gee, \& Jones, 1998; Teece, Pisano, \& Shuen, 1997), cognitive abilities and competences (Primi et al., 2001), and communication effectiveness (Rego, 2001). Thus, literature emphasizes the roles of knowledge and people in organizational productivity. Based on this new paradigm, managers are changing financial reporting mechanisms to new procedures based on knowledge measurement (Fruin, 1997; Hall, 1992; Hamel \& Prahalad, 1994; Snell, Lepak, \& Youndt, 1999).

The benchmark theory we present next is based on Bontis' IC model in terms of concept and taxonomy. We also develop different approaches that investigate the relationship between IC and productivity. Thus, we set up the basic hypothesis of this research, which is to be tested later. The following section describes the research method. Then we analyze the data collected and the research hypothesis being tested. Finally, we elaborate the discussion and present recommendations for future studies, so that the exploratory propositions formulated in this paper can be tested.

\section{The Bontis model of intellectual capital}

A variety of classification schemes and models have been deployed in regards to IC theoretical framework (e.g., Bontis, 1998, 2002; Brooking, 1997; Chen, Zhu, \& Yuan, 2004; McElroy, 2002; Petty \& Guthrie, 2000; Roos, Bainbridge, \& Jacobsen, 2001). In our study, we adopted the widely established Bontis model (1998), that divides IC into three main components: (a) Human Capital: knowledge and skills of individuals; (b) Structural Capital: internal processes and information that are property of the organization; and (c) Customer/Relational Capital: relationships the organization has with its stakeholders (Bontis, 1998; Ferreira \& Martinez, 2008; Stewart, 1997). This model has generally been accepted in current literature (Atrill, 1998; Dzinkowski, 2000; Lynn, 1998).

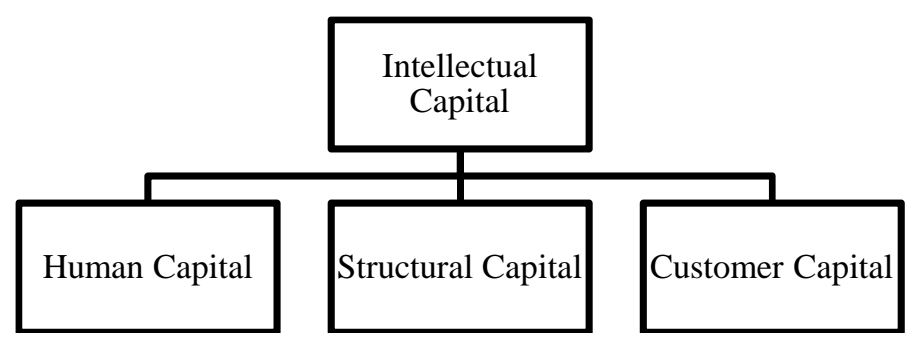

Figure 1. Conceptualization of Intellectual Capital

Fonte: Bontis, N. (1998). Intellectual capital: an exploratory study that develops measures and models (p. 66). Management Decision, 36, 63-76. 


\section{Human capital}

Human Capital represents the knowledge acquired from individual employee's skills, experience and expertise. In this sense, distinct employee profiles provide diverse components of human capital, bringing added value to the organizational assets. Thus, Human Capital is a source of tacit knowledge and is acquired through experience and explicit knowledge. It can be enhanced by social relations, human value improvements and organizational commitment (Tamayo et al., 2001). Also, by mobilizing collaborators to participate in daily organizational routines, the organizational productivity increases (Adler \& Kwon, 2002; Reed, Lubatkin, \& Srinivasan, 2006; Sharabati, Jawad, \& Bontis, 2010; Teixeira \& Popadiuk, 2003). High levels of Human Capital can reduce the amount of time and investment necessary to obtain information and solve problems (Burt, 1992). This crucial dimension of IC involves essential knowledge to perform tasks and is considered its most complex dimension because it is difficult to imitate or replace (Walsh, Enz, \& Canina, 2008).

\section{Structural capital}

Also termed as Systems Capital (Walsh et al., 2008), Structural Capital represents all nonhuman stocks of codified knowledge in an organization. It embodies what remains in the organization when the employees leave to go home at night (Roos et al., 2001). In other words, Structural Capital encompasses everything that still exists after working hours - such as relationships with suppliers, clients, local commodities, government, and shareholders. This factor is considered the one that can best predict levels of performance (Adler \& Kwon, 2002; Kostova \& Roth, 2003; Youndt $\&$ Snell, 2004). Poor levels of Structural Capital denote a lack of ability to organize an organization's workforce in order to produce and deliver its product. Consequently, it would fail to return on investments in all other forms of IC (Bontis, 1998). In this sense, organizations must provide ergonomic conditions to promote better human-machine interactions (Abrahão, Silvino, \& Sarmet, 2003).

\section{Customer capital}

This component is somewhat similar to that referred to as External Social Capital by sociologists (Bourdieu, 1985; Coleman, 1998) and management theorists (Adler \& Kwon, 2002; Youndt, Subramaniam, \& Snell, 2004). Customer Capital is considered a market-based asset that is obtained through affiliation with a brand. It deals with the external environment, and consists of knowledge about marketing, customer appeal and distribution channels (Baker, 1990). The brand name itself is considered one of the biggest contributors to Customer Capital. The main goal for improving this dimension is to attract new customers and retain current ones (Keller, 1993).

\section{IC and productivity}

Companies with higher levels of success should be the ones that take intangible management goods into consideration and possess relevant strategic tools (Dorweiler \& Yakhou, 2005; Swanson, 1999). It is crucial for organizations to identify their IC in order to raise productivity levels, sustain competitive advantages and generate added future value (Davenport \& Prusak, 1998; Dierickx \& Cool, 1989; Youndt, Snell, Dean, \& Lepak, 1996). Human Capital development is important to generate and increase productivity (Youndt \& Snell, 2004). Moreover, Structural Capital is one of the IC dimensions that best predicts performance (Adler \& Kwon, 2002; Kostova \& Roth, 2003; Youndt \& Snell, 2004).

A study conducted by Youndt and Snell (2004) revealed that an investment in three key areas, such as HRM (human resource management), IT (information technology) and R\&D (research and development) is generally associated with organizations having high levels of IC. Other studies have shown that IC mediates the relationship between HRM practices and organizational performance (Yang \& Lin, 2009). As mentioned above, IC is an extremely important factor to organizations, since 
it increases their competitive activities. Therefore, the devaluation of IC might lead to a decline in business success (Caddy, 2002; Joia \& Malheiros, 2010; Kaplan \& Norton, 2004). However, previous research permits us to conclude that the majority of organizations are centered on only one of the dimensions of Human Capital, whereas investments in HRM are acutely present in companies with higher concern for the human and social capital areas. On the other hand, a greater investment in IT is noticeable in companies with a social capital profile (Youndt et al., 2004).

Stemming from the previous viewpoint, our research led to the need to analyze how executives' perceptions of investment area priority are related to IC organizational dimensions. Perceptions of investment are fundamental because they may help managers better their practices and enhance the desire for organizational improvement (Barney, 1991; Bontis, 1996; Hamel \& Prahalad, 1994). An additional motive of our study was to analyze different perceptions of organizational productivity and their relation to IC components. Thus, we sought to understand perceptions of organizational productivity in companies with different dominant profiles of IC: Human, Structural and Customer Capital.

\section{Method}

\section{Participants}

Our sample consisted of 440 workers from Portuguese organizations operating in the service (third) sector. The majority of participants (almost 80\%) worked mainly in the Lisbon area and its surrounding areas (13 organizations). The remaining 20\% were located in Oporto (2 organizations) and Aveiro (1 organization). Within each organization, four strata of staff were represented: (a) people responsible for the organization (e.g., CEOs and/or company owners); (b) top managerial roles (e.g., directors); (c) middle management roles (e.g., heads of departments and supervisors); and (d) staff engaged in technical managerial roles (e.g., information technologies, marketing, human resources, finance). The number of respondents in each group was as follows: CEOs $(n=46)$, top managers $(n=$ $74)$, middle managers $(n=82)$ and technical managers $(n=238)$. Almost half of the sample $(47.7 \%)$ consisted of individuals who engaged in leadership functions.

\section{Materials, procedure and variables}

Participants were told that the study involved the measurement of perceptions, thoughts and feelings about organizational reality. All questionnaires were distributed individually by their responsible (when appropriate) and then returned to the human resources department.

First, each participant completed the Intellectual Capital Scale (ICS) (Ferreira, 2010; Ferreira, Costa, \& Santos, 2009), a 16 item scale that measures three dimensions of intellectual capital: (a) Customer Capital; (b) Structural Capital; and (c) Human Capital. All items consisted of affirmative sentences associated with a seven alternative Likert answer scale, ranging from 1 (totally disagree) to 7 (totally agree). Items were derived from the theoretical conceptualization of intellectual capital from previous scales measuring intellectual capital dimensions (Adler \& Kwon, 2002; Atrill, 1998; Bontis, 1998; Dzinkowski, 2000; Lynn, 1998; Youndt \& Snell, 2004). Scale dimensions reported appreciable psychometric values with Cronbach Alphas ranging from .62 for Structural Capital to .92 for Human Capital (Ferreira, 2010; Ferreira et al., 2009).

Second, we asked participants their thoughts about the area of highest priority for investment in their specific organization (i.e., the area that needed a greater level of investment). They could choose one of three different investment areas in their organizations: (a) marketing and sales $(n=190)$; (b) human resources and research $(n=226)$; and (c) technology and infrastructure $(n=18)$. 
Third, all participants were invited to indicate their perception of their company's productivity, by choosing a value scale ranging from 1 (not productive at all) to 7 (extremely productive). In order to conduct a more precise analysis, our sample was split in two parts concerning productivity: (a) upward trend: participants who expect a rise in their organization's productivity levels $(n=329)$; (b) downward trend: those executives who perceive difficulties and expect productivity levels to fall $(n=$ 112).

\section{Results}

\section{IC and perceptions of areas needing investment}

First of all, we asked all participants about areas of highest priority for investment in their organization. Then, we measured the relation between those areas and IC components. In order to compare the different perceptions of necessary investment with the measures of IC, several ANOVA's were conducted. Previous Kolmogorov-Smirnov analysis revealed that our data were normally distributed. The results are shown in Figure 2. Our data revealed significant differences across investment areas in all IC groups: Customers Capital, $F(2,431)=3.99, p<.05, \eta^{2} \mathrm{p}=.017 ; \pi=.685$; Human Capital, $F(2,431)=3.99, p<.05, \eta^{2} \mathrm{p}=.018 ; \pi=.715$; and Structural Capital, $F(2,431)=8.16$, $p<.01, \eta^{2} \mathrm{p}=.036 ; \pi=.959$.

Post-hoc comparison tests (Scheffe) illustrate the discrepancies between the perception of investment needed and the three dimensions of IC. These results reveal that a high score on Structural Capital is significantly associated with a higher perception of lack of investment in human resources and research when compared with marketing and sales (Mean Difference $=.402, p<.001$ ). The other IC dimensions (Human and Customer), although not significant, did not exhibit substantial differences with respect to investment priorities.



Figure 2. Areas of Investment Priorities According to the three Dimensions of Intellectual Capital.

\section{IC and perception of productivity}

In order to test the impact of IC on productivity perception we conducted a first regression analysis (stepwise method), in which we examined three dimensions of IC on the 1-7 point factor perceived productivity (Table 1). According to our results only two of the predictor variables were significant: Structural $(\beta=.578 ; p<.001)$ and Customer $(\beta=-.155 ; p<.001)$. In this case, Structural Capital corresponds positively, and Customer Capital correlates negatively, with the factor perceived productivity. Overall, those two dimensions of intellectual capital accounted for $29.9 \%$ of the variance of the factor perceived productivity (adjusted $R^{2}=.299$ ). 
Next, we analyzed how different hierarchic positions affect the relationship between dimensions of intellectual capital and perceived productivity. We divided our sample by organizational functions and conducted the same hierarchical regression procedures. Our data showed that for CEO's, Top Managers and Technical Managers only Structural Capital corresponds positively with perceived productivity $(\beta=.684, p<.001 ; \beta=.669 ; p<.001 ; \beta=.403, p<.001$, respectively). In regards to Middle Managers, all three predictor variables were significant: Structural $(\beta=.260 ; p<.05)$, Human $(\beta=.266 ; p<.05)$, and Customer $(\beta=-.293 ; p<.05)$. Overall, these dimensions accounted for $25.3 \%$ of the perceived productivity.

Table 1

Regression Model for Intellectual Capital Predictors of Perceived Productivity (n=440)

\begin{tabular}{ccccc}
\hline & & B & SD B & $\beta$ \\
\hline \multirow{2}{*}{ Step 1 } & Constant & 2.04 & .24 & $.530^{*}$ \\
& Structure & .63 & .05 & $.578^{*}$ \\
& Constant & 2.79 & .310 & .050 \\
& Structure & .69 & .052 & $-.155^{*}$ \\
\hline
\end{tabular}

Note. $\Delta \mathrm{R}^{2}=.279$ for Step $1 ; \Delta \mathrm{R}^{2}=.299$ for Step $2(p<.001) ; * p<.001$

Moreover, to test differences between the two groups of organizational productivity perception (i.e., upward vs. downward trend), t-tests were applied to the scores of the three principal components of IC that were measured. Our results highlight differences for two dimensions of IC: Customer, $t$ $(434)=2.29, p=.03$ and Structural, $t(432)=13.62, p<.01$. Managers who foresaw a period of decline were found to have a significantly lower mean score $(M=5.17 ; S D=1.12)$ on Customer Capital than managers from more highly productive organizations $(M=5.43 ; S D=.98)$. Moreover, for Structural Capital, workers from more productive companies have higher scores $(M=5.09 ; S D=$ $.82)$ than people from non-productive organizations $(M=3.78 ; S D=1.02)$. No significant results were found for the Human Capital dimension.

\section{Discussion}

The aim of this research was to reveal different perceptions of investment and organizational productivity according to different realities of intellectual capital (IC) practices. Moreover, we explored different perceptions of multiple facets of IC in order to recognize how these organizational representations affect employees' perceptions concerning investment and productivity. IC is undoubtedly a factor of extreme importance to organizations, since it increases its competitive activities (Snell et al., 1999). Furthermore, the eventual underestimation of IC would more likely lead organizations towards failure (Caddy, 2002; Grant, 1996; Kaplan \& Norton, 2004).

Our empirical results reveal that organizations with high scores of Structural Capital tend to promote perceptions of a lack of investments in human resources and research. These results enhance the importance for business support and the need to provide additional information. Managers have to highlight that structural investment is important to enhance human resource management, working life quality, and productivity. Employees have to be aware that Structural Capital means a return of investment in all other forms of IC (Bontis, 1998). In fact it helps employees organize the workforce, facilitate production, and enhance product delivery capacity (Bontis, 1998). 
Additionally, our data also show that two dimensions of IC predict $29.9 \%$ of the variance associated with perceived productivity: Structural Capital has a positive association, as opposed to Customer Capital, which has a negative association. These results highlight the importance for structural investments in service organizations, as they are highly associated with perceived productivity. Managing technology flows (Allen, 1977; Dosi, 1982) also plays a key role in this phenomenon. Accordingly, previous research showed that Structural Capital is considered the factor that can best predict the level of performance and productivity (Adler \& Kwon, 2002; Kostova \& Roth, 2003; Youndt \& Snell, 2004). Moreover, other studies also identify Structural Capital as the most prominent component of IC (e.g., Martinez-Torres, 2006).

We also point out that Customer Capital negatively affects perceived productivity because the employees studied are from the service sector and externalize the need for structures, infrastructure and technology. They will never report that one weakness of their organization is Customer Capital because it depends directly upon their work. Moreover, when asked to point out the actual organizational state in terms of productivity we can notice that workers with higher scores of Customer and Structural Capital mention that their company would be identified as being in an ascendant phase. This data enhances the importance of Customer and Structural Capital investments, not only because of perceived productivity, but also because perceptions are normally associated with objective organizational situations (Hansen, Nohria, \& Tierney, 1999).

On the other hand, even though the Human Capital dimension has been recognized as an important dimension of IC, it does not seem to affect perceived perception and does not discriminate between companies in different phases of perceived productivity evolution. This fact may be associated with the scale of psychometric properties, exhibiting lower Cronbach alpha results for the dimension of Human Capital. This may be due to higher levels of associated error. In accordance with these findings, it is necessary to replicate our findings with other studies involving new IC measures and other dimensions of Human Capital, due to the fact that human resource management systems are in an area where human capital development plays a fundamental role. This is one reason why many researchers suggest that companies having the possibility of acquiring or developing human capital should do so (Yang \& Lin, 2009; Youndt \& Snell, 2004).

In closing, it is vital to highlight the importance of IC investments, because for companies to have greater success, they must take intangible management assets into consideration and possess relevant strategic tools (Dorweiler \& Yakhou, 2005; Joia \& Malheiros, 2010; Swanson, 1999). Organizations with higher levels of IC will be those where the value added services of the firm come from their professional knowledge and capacity for organizational learning, as well as from the protection and security of proprietary information (Bontis, 1996, 1998). In sum, tangible resources (e.g., financial measures) should be complemented with IC measures (Holmen, 2005), considering IC is correlated with the systems, processes, intellectual richness, organizational culture and high financial returns of companies (Abeysekera, 2003, 2005; Andriessen, 2007; Lev \& Zambon, 2003).

\section{Artigo recebido em 11.12.2009. Aprovado em 09.09.2010.}

\section{References}

Abeysekera, I. (2003). Intellectual accounting scorecard - measuring and reporting intellectual capital. Journal of American Academy of Business, 3(1-2), 422-427.

Abeysekera, I. (2005). Intellectual capital. Financial Management, 31, 35-36.

Abrahão, J. I., Silvino, A. M., \& Sormet, M. M. (2003). Ergonomia, cognição e trabalho informatizado. Psicologia: Teoria e Pesquisa, 21(2), 163-171. doi: 10.1590/S010237722005000200006 
Intellectual Capital: Productivity and Investment Perceptions

Adler, P. S., \& Kwon, S. (2002). Social capital: prospects for a new concept. Academy of Management Review, 27(1), 17-40. doi: 10.2307/4134367

Allen, T. (1977). Managing the flow of technology: technology transfer and the dissemination of technological information within the $R \& D$ organization. Cambridge, MA: MIT Press.

Andriessen, D. (2007). Designing and testing an OD intervention: reporting intellectual capital to develop organizations. Journal of Applied Behavioral Science, 43(1), 89-107. doi: $10.1177 / 0021886306297010$

Argyris, C., \& Schon, D. A. (1978). Organizational learning: a theory of action perspective. Reading, MA: Addision-Wesley.

Atrill, P. (1998). Intellectual assets: the new frontier. ACCA Students' Newsletter, 34, 56-59.

Baker, W. (1990). Market networks and corporate behavior. American Journal of Sociology, 96(3), 589-625.

Barney, J. (1991). Firm resources and sustained competitive advantage. Journal of Management, 17(1), 99-120. doi: 10.1177/014920639101700108

Becker, G. S. (1964). Human capital. New York: Columbia University Press.

Bontis, N. (1996). There's a price on your head: managing intellectual capital strategically. Business Quarterly, 60, 40-47.

Bontis, N. (1998). Intellectual capital: an exploratory study that develops measures and models. Management Decision, 36(2), 63-76. doi: 10.1108/00251749810204142

Bontis, N. (2002). National intellectual capital index: intellectual capital development in the Arab region. Ontario, Canada: Institute for Intellectual Capital Research.

Bourdieu, P. (1985). The forms of capital. In J. Richardson (Ed.), Handbook of theory and research for the sociology of education (pp. 241-258). New York: Greenwood.

Brooking, A. (1997). El capital intelectual: el principal activo de las empresas del tercer milenio [Intellectual capital: core asset for the third millennium enterprise]. Barcelona, Spain: Paidós Ibérica.

Burt, R. S. (1992). Structural holes: the social structure of competition. Cambridge, MA: Harvard University Press.

Caddy, I. (2002). Intellectual capital: recognizing assets and liabilities. Journal of Intellectual Capital, 1(29), 129-136.

Chen, J., Zhu, Z., \& Yuan, H. (2004). Measuring intellectual capital: a new model and empirical study. Journal of Intellectual Capital, 5(1), 195-212. doi: 10.1108/14691930410513003

Cohen, W. M., \& Levinthal, D. A. (1990). Absorptive capacity: a new perspective on learning and innovation. Administrative Science Quarterly, 35(1), 128-152. doi: 10.2307/2393553

Coleman, J. (1998). Social capital in the creation of human capital. American Journal of Sociology, 94, S95-S120. doi: 10.2307/2780243

Conner, K., \& Prahalad, C. K. (1996). A resource-based theory of the firm: knowledge versus opportunism. Organization Science, 7(5), 477-501. doi: 10.1287/orsc.7.5.477

Daft, R. L., \& Weick, K. E. (1984). Toward a model of organizations as interpretation systems. Academy of Management Review, 9(2), 284-295. 
Davenport, T. H., \& Prusak, L. (1998). Working knowledge: how organizations manage what they know. Boston, MA: Harvard Business School Press.

Dierickx, I., \& Cool, K. (1989). Asset stock accumulation and sustainability of competitive advantage. Management Science, 35(12), 1504-1511. doi: 10.1287/mnsc.35.12.1504

Dorweiler, V., \& Yakhou, M. (2005). A scorecard on intellectual capital performance in the economy. The Journal of American Academy of Business, 7(1), 322-326.

Dosi, G. (1982). Technical paradigms and technological trajectories: a suggested interpretation of the determinants and directions of technical change. Research Policy, 11(3), 147-162. doi: 10.1016/0048-7333(82)90016-6

Duncan, R., \& Weiss, A. (1979). Organizational learning: implications for organizational design. Research in Organizational Behavior, 1, 75-123.

Dzinkowski, R. (2000). The measurement and management of intellectual capital: an introduction. Management Accounting, 78(2), 32-36.

Edvinsson, L., \& Malone, M. S. (1997). Intellectual capital: Realizing your company's true value by finding its hidden brainpower. New York: Harper Business.

Ferreira, A. I. (2010). Construction and factorial validity of the intellectual capital scale. Hellenic Journal of Psychology, 7(2), 124-140.

Ferreira, A. I., Costa, C., \& Santos, R. (2009). How to measure human capital? A new scale to measure intellectual capital. In E. Morin, N. Ramalho, J. Neves, \& A. Savoie (Orgs.), New research trends in effectiveness, health, and work: a criteos scientific and professional account (pp. 355-367). Montreal: Criteos/HEC-Montreal.

Ferreira, A. I., \& Martinez, L. F. (2008). Manual de diagnóstico e mudança organizacional. Lisboa: RH Editora.

Flamholtz, E. G., \& Lacey, J. M. (1981). Personnel management, human capital theory, and human resource accounting. Los Angeles, CA: Institute of Industrial Relations, University of California.

Fruin, M. W. (1997). Knowledge works: managing intellectual capital at Toshiba. New York: Oxford University Press.

Grant, R. M. (1996). Prospering in dynamically-competitive environments: organizational capability as knowledge integration. Organization Science, 7(4), 375-387. doi: 10.2307/2635098

Hall, R. (1992). The strategic analysis of intangible resources. Strategic Management Journal, 13(2), 135-144. doi: 10.1002/smj.4250130205

Hamel, G., \& Prahalad, C. K. (1994). Competing for the future. Boston, MA: Harvard Business School Press.

Hansen, M. T., Nohria, N., \& Tierney, T. (1999). What's your strategy for managing knowledge? Harvard Business Review, 77, 106-116.

Henderson, R., \& Cockburn, I. (1994). Measuring competence? Exploring firm effects in pharmaceutical research. Strategic Management Journal, 15(Suppl.), 15-26. doi: $10.1002 / \mathrm{smj} .4250150906$

Holmen, J. (2005). Intellectual capital reporting. Management Accounting Quarterly, 6(4), 308-329. 
Hudson, W. (1993). Intellectual capital: how to build it, enhance it, use it. New York: Wiley.

Joia, L. A., \& Malheiros, R. (2010). Evidências empíricas da influência de alianças estratégicas no capital intelectual de empresas. Revista de Administração e Contabilidade de Unisinos, 7(2). doi: 162-177. 10.4013/base.2010.72.07

Kaplan, R. S., \& Norton, D. P. (2004). Strategy maps: converting assets into tangible outcomes. Boston, MA: Harvard Business School Press.

Keller, K. L. (2003). Strategic brand management: building, measuring and managing brand equity (2nd ed.). New Jersey: Prentice Hall.

Klein, J., Gee, D., \& Jones, H. (1998). Analysing clusters of skills in R\&D - core competencies, metaphors, visualization, and the role of IT. $R \& D$ Management, 28(1), 37-42. doi: $10.1111 / 1467-9310.00079$

Kostova, T., \& Roth, K. (2003). Social capital in multinational corporations and a micro-macro model of its formation. Academy of Management Review, 28(2), 297-317.

Lev, B., \& Zambon, S. (2003). Intangibles and intellectual capital: an introduction to a special issue. European Accounting Review, 12(4), 597-603. doi: 10.1080/0963818032000162849

Lynn, B. (1998). Intellectual capital. CMA Management, 72, 10-15.

Martinez-Torres, M. R. (2006). A procedure to design a structural and measurement model of intellectual capital: an exploratory study. Information \& Management, 43(5), 617-626. doi: 10.1016/j.im.2006.03.002

McElroy, M. (2002). Social innovation capital. Journal of Intellectual Capital, 3(1), 30-39. doi: $10.1108 / 14691930210412827$

Nicolaci-da-Costa, A. M. (2002). Revoluções tecnológicas e transformações subjectivas. Psicologia: Teoria e Pesquisa, 18(2), 193-202. doi: 10.1590/S0102-37722002000200009

Petty, R., \& Guthrie, J. (2000). Intellectual capital literature review: measurement, reporting and management. Journal of Intellectual Capital, 1(2), 155-176. doi: 10.1108/14691930010348731

Primi, R., Santos, A. A., Vendramini, C. M., Taxa, F., Muller, F. A., Lukjanenko, M. F., \& Sampaio, I. S. (2001). Competencias e habilidades cognitivas: diferentes definições dos mesmos constructos. Psicologia: Teoria e Pesquisa, 17(2), 151-159. doi: 10.1590/S010237722001000200007

Reed, K. K., Lubatkin, M., \& Srinivasan, N. (2006). Proposing and testing an intellectual capitalbased view of the firm. Journal of Management Studies, 43(4), 867-893. doi: 10.1111/j.14676486.2006.00614.x

Rego, A. (2001). Eficácia comunicacional na docência universitária - A perspectiva de estudantes e professores. Psicologia: Teoria e Pesquisa, 17(3), 275-284. doi: 10.1590/S010237722001000300010

Roos, G., Bainbridge, A., \& Jacobsen, K. (2001). Intellectual capital as a strategic tool. Strategic and Leadership, 29(4), 21-26. doi: 10.1108/10878570110400116

Sharabati, A., Jawad, S., \& Bontis, N. (2010). Intellectual capital and business performance in the pharmaceutical sector of Jordan. Management Decision, 48(1), 105-131. doi: $10.1108 / 00251741011014481$ 
Snell, S. A., \& Dean, J. W. (1992). Integrated manufacturing and human resources management: a human capital perspective. Academy of Management Journal, 35(3), 467-504.

Snell, S. A., Lepak, D. P., \& Youndt, M. A. (1999). Managing the architecture of intellectual capital: implications for strategic human resource management. In G. R. Ferris (Ed.), Research in Personnel and Human Resources Management, 17(S4), 175-193.

Stewart, T. A. (1997). Intelectual capital: the new wealth of organizations. New York: Doubleday/Currency.

Swanson, R. (1999). The foundations of performance improvement and implications for practice. Advances in Developing Human Resources, 1(1), 1-25. doi: 10.1177/152342239900100102

Tamayo, A., Souza, M. G., Vilar, L. S., Ramos, J. L., Albernaz, J. V., \& Pereira, N. P. (2001). Prioridades axiológicas e comprometimento organizacional. Psicologia: Teoria e Pesquisa, 17(1), 27-35. doi: 10.1590/S0102-37722001000100006

Teece, D., Pisano, G., \& Shuen, A. (1997). Dynamic capabilities and strategic management. Strategic Management Journal, 18(7), 509-533. doi: 10.1002/(SICI)1097-0266(199708)18:7<509::AIDSMJ882>3.0.CO;2-Z

Teixeira, M. L. M., \& Popadiuk, S. (2003). Confiança e desenvolvimento de capital intelectual: o que os empregados esperam de seus líderes? Revista de Administração Contemporânea, 7(2), 73-92. doi: $10.1590 / \mathrm{S} 1415-65552003000200005$

Walsh, K., Enz, C. A., \& Canina, L. (2008). The impact of strategic orientation on intellectual capital investments in customer service firms. Journal of Service Research, 10(4), 300-317. doi: $10.1177 / 1094670508314285$

Yang, C., \& Lin, C. (2009). Does intellectual capital mediate the relationship between HRM and organizational performance? Perspective of a healthcare industry in Taiwan. International Journal of Human Resource Management, 20(9), 1965-1984. doi: 10.1080/09585190903142415

Youndt, M. A., \& Snell, S. (2004). Human resource configurations, intellectual capital, and organizational performance. Journal of Managerial Issues, 16(3), 337-360.

Youndt, M. A., Snell, S. A., Dean, J. W., \& Lepak, D. P. (1996). Human resource management, manufacturing strategy, and firm performance. Academy of Management Journal, 39(4), 836866. doi: $10.2307 / 256714$

Youndt, M. A., Subramaniam, M., \& Snell, S. A. (2004). Intellectual capital profiles: an examination of investments and returns. Journal of Management Studies, 41(2), 335-361. doi: 10.1111/j.1467-6486.2004.00435.x 